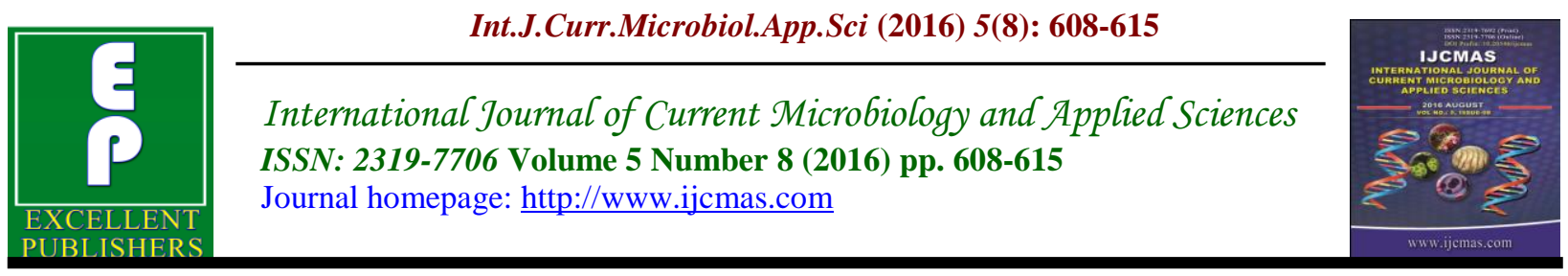

Original Research Article

http://dx.doi.org/10.20546/ijcmas.2016.508.068

\title{
Genetic Analysis of Madhuca longifolia (J. Koenig ex L.) J.F. Macbr. Using RAPD Markers
}

\author{
Rohan Gavankar* and Maya Chemburkar \\ Department of Botany, Bhavan's College, Andheri West, India \\ *Corresponding author
}

A B S T R A C T

\begin{abstract}
Keywords
Madhuca

longifolia,

RAPD,

Genetic diversity,

dendrogram.

Article Info

Accepted:

23 July 2016

Available Online:

10 August 2016

Madhuca longifolia commonly known as mahua belongs to family Sapotaceae. It is an important non-timber economic tree which has two varieties namely Madhuca longifolia var. latifolia and Madhuca longifolia var. longifoliae. These two varieties show remarkably similarity in their economic use and phytochemistry. Mahua tree grows wildly and is also cultivated in norther and southern part of India. The two varieties differ morphologically with respect to the leaf hence the names. RAPD profile was optimized to study the genetic variability in mahua using randomly selected 10 genotypes. The profile was developed using 10 decamer primers. The dendrogram was constructed using UPGMA algorithm. Our results highlighted the use of RAPD markers to gain simple and lucid information about the genetic similarities or dissimilarities in the two varieties that might not be so easily evident from other commonly used techniques.
\end{abstract}

\section{Introduction}

Madhuca indica and Madhuca longifolia were two species found in India which are categorized as two varieties due to remarkable similarities as Madhuca longifolia var latifoliasyn M.indica and Madhuca longifolia var longifolia. Both of these are geographically distinguished as North Indian mahua and South Indian mahua respectively.

Inter and intra specific components characterize biodiversity and these assessments have been carried out by field study and taxon survey by ecologist and taxonomist. A genetic resource management strategy for such variations in species needs to be based on research data examining the extent of genetic differentiation within and between populations and on understanding the processes maintaining this variation (Chelliah et al., 2010). Genotype fingerprinting is also an important tool which can remove any duplicates that are introduced through mislabeling or during multiplication in clonal propagation of plants (Shivashankar, 2014).

There is less information available on the existing germplasm diversity in Madhuca longifolia and, therefore, cataloguing of natural genetic diversity becomes essential 
for its efficient and sustainable germplasm management.

Polymerase Chain Reaction (PCR) based molecular markers such as Randomly Amplified Polymorphic DNA (RAPD) technology has become an efficient tool in investigation of genetic diversity within and between populations and has been explored by molecular biologist (Singh et al., 2002; Belaj et al., 2002; Shan et al., 2005).

Madhuca longifolia commonly called mahua is one of the most harnessed non timber trees. Several pharmacological activities have been reported about the various parts of the plant. It is also considered as valued and sacred tree by several tribes in different states of India (Patil et al, 2004).

Our research is hence focused on the genetic diversity which was carried out to determine intra -specific or inter-varietal variations in randomly selected genotypes of Madhuca longifolia.

\section{Materials and Methods}

\section{Collection of samples}

Plant samples used in the present study were fresh young leaves of 10 genotypes of Madhuca longifolia (J.Koenig ex L.) J.F. Macbr.belonging to family Sapotaceae. 8 genotypes were randomly selected belonging to Madhuca longifolia var. latifolia from Bhavans college campus and Wada, Taluka Vasai, Dist. Palghar, Maharashtra, India.1 genotypewas the leaves of Madhuca longifolia var. longifolia purchased from nursery in Chennai, Tamilnadu. 1 genotype was cultivated genotype of Madhuca longifolia var. longifolia taken from bhavans college campus. The leaf samples of these 10 genotypes were collected fresh and were carried to laboratory in a zip-lock bag containing packet of silica gel.

\section{DNA extraction and quantification}

Optimized protocol comprising of $1 \%$ CTAB buffer with homogenization in liquid nitrogen followed by grinding with a pinch of PVP was used for extraction of DNA from the randomly selected 10 genotypes which were further subjected to RAPD analysis.

\section{Reagents and the optimal $\mathrm{PCR}$ reaction mixture}

PCR amplification was done in $20 \mu \mathrm{l}$ of reaction volume containing $1 \mathrm{x}$ PCR buffer (Kappa, SA); $\mathrm{MgCl}_{2}, 3 \mathrm{mM}$; dNTP mix, $0.25 \mathrm{mM}$; Taq DNA polymerase, $0.05 \mathrm{U}$; primer, 1 pmol and template DNA, $50 \mathrm{ng}$. Sterile nuclease free water is used as negative control.

\section{Agarose gel electrophoresis}

Agarose gel electrophoresis is the most simplest and economic way for visualization and analysis of DNA to quantify it or to isolate a particular band. $1 \mathrm{~g}$ agarose was dissolved into $50 \mathrm{ml}$ TAE (Tris Acetic acid Electrophoresis) buffer to get a $2 \%$ gel. The agarose was digested in microwave oven so as to get a translucent solution. $2 \mu$ lof ethidium bromide (DNA staining dye) was added to it, mixed properly before pouring into the gel casting tray containing the comb and allowed to set for $45 \mathrm{~min}$. The Comb was carefully removed to avoid damage to the wells. About $300 \mathrm{ml}$ of $1 \mathrm{X}$ solution of TAE buffer was added to the buffer tank of horizontal electrophoretic set up. $10 \mu l$ of sample with the gel loading dye containing bromophenol blue as the 
tracking dye was loaded in the wells of the gel. $8 \mu \mathrm{l}$ of $100 \mathrm{bp}$ DNA ladder (Bangalore genei) was also loaded into one well as standard. The gel electrophoresis was carried out using Electrophoresis unit. Power supply was turned on to about 50 volts for 30 minutes and then to 100 volts. The gel was viewed in UV-illuminator. The DNA band pattern was observed and photographed using digital camera.

\section{Genetic Diversity DATA Analysis}

The 10 RAPD markers resulted in different banding pattern ranging from 100-2000bp. For construction of a dendrogram, presence and absence of bands were scored as 1 and 0 respectively. Using the UPGMA statistical software, diversity between the samples was analyzed using Paired group algorithm with similarity matrix based on Jaccard coefficient.

\section{Results and Discussion}

The 10 genotypes yielded good quality DNA ranging from $530(\mu \mathrm{g} / \mathrm{gm})$ to $812(\mu \mathrm{g} / \mathrm{gm})$ and the ratio of $(260 / 280)$ also ranged from 1.7 to 1.8. Extraction of DNA from Madhuca longifolia was carried out by optimized DNA method using CTAB buffer system. The extracted DNA was further used to carry out PCR amplification using 10 Decamer primers to generate RAPD profile discussed as follows

Genetic relationship among the ten randomly selected genotypes of two varieties Madhuca longifolia was carried out using RAPD finger printing analysis. 10 random primers selected generated reproducible, informative and easily analyzable RAPD profiles. 4 primers gave 6 unique bands primer $1-1$ unique band, primer 5 and 6 two unique bands and primer 91 unique band was scored. Only Primer 8 gave monomorphic bands whereas rest of the 9 primers no monomorphic bands were scored.

In cluster analysis of the dendrogram revealed that S-5 the genotype collected from Wada formed a separate clade, this genotype grows wild in the industrial area shows delayed flowering and fruits of smaller size. The second cluster showed similarity between S6 and S3 and a clade of $\mathrm{S} 7$ and S9. The innermost cluster revealed the similarity between $\mathrm{S} 1$ and $\mathrm{S} 2$ and its relatedness to S4. The two genotypes of Madhuca longifolia var. longifoliaS8 and S10 were geographically distinct but indicate similarity in the genetic constitution. The variety Madhuca longifolia var. longifolia differs from variety Madhuca longifolia var. latifoliabut is not very significantly different genetically.

The genotypes taken for study suggested that Madhuca longifolia var. longifolia and Madhuca longifolia var. latifolia undergoes a major part of genetic variation by environmental factors. The genetic diversity of Madhuca longifolia varies with the geographic distance and environmental factors. Genetic diversity refers to the variation at the level of polymorphism in individual genes, and provides a mechanism for populations to adapt their ever-changing environment (Chelliah et al., 2010). Variation in the genetic constitution may results in offspring with better chances of changing environmental conditions. 


\section{Table.1 PCR-MIX}

\begin{tabular}{|l|c|}
\hline PCR components & Volume $(\mu \mathrm{l})$ \\
\hline Nuclease free water & 10.75 \\
\hline 10X reaction buffer with $\mathbf{M g C l}_{\mathbf{2}} \mathbf{( 1 . 5 m M )}$ & 2.00 \\
\hline dNTP mix $(\mathbf{2 . 5 m M )}$ & 2.00 \\
\hline Primer 16S FP (10picomoles/ $\boldsymbol{\mu l})$ & 2.00 \\
\hline Primer 16S RP (10picomoles/ $\boldsymbol{\mu l})$ & 2.00 \\
\hline Taq DNA polymerase $\mathbf{( 5 U )}$ & 0.25 \\
\hline Template DNA $(\mathbf{5 0 n g} / \boldsymbol{\mu l})$ & 1.00 \\
\hline Total volume & $\mathbf{2 0 . 0}$ \\
\hline
\end{tabular}

Table.2 List of RAPD primers used

\begin{tabular}{|c|c|c|c|}
\hline SR. No & Sequence $\left(5^{\prime}-3^{\prime}\right)$ & SR. No & Sequence $\left(5^{\prime}-3^{\prime}\right)$ \\
\hline 1 & AGACGGCTCC & $\mathbf{6}$ & CTACGCTCAC \\
\hline 2 & GAGACCAGAC & $\mathbf{7}$ & AGATGGGCAG \\
\hline 3 & TTAGCGCCCC & $\mathbf{8}$ & TGGTCGGGTG \\
\hline 4 & AGGACTGCTC & $\mathbf{9}$ & GGACCCAACC \\
\hline 5 & GTGGGTGCCA & $\mathbf{1 0}$ & CAGGCCCTTG \\
\hline
\end{tabular}

Table.3 PCR temperature profile

\begin{tabular}{|l|l|l|l|l|}
\hline $\begin{array}{l}\text { Initial } \\
\text { denaturation }\end{array}$ & Denaturation & Annealing & Extension & Final Extension \\
\hline $94^{\circ} \mathrm{C}$ & $\mathbf{9 4}^{\mathbf{0}} \mathbf{C}$ & $\mathbf{3 7}^{\mathbf{0}} \mathbf{C}$ & $\mathbf{7 2}^{\mathbf{0}} \mathbf{C}$ & $\mathbf{7 2}^{\mathbf{0}} \mathbf{C}$ \\
\hline $5 \mathrm{~min}$ & $1 \mathrm{~min}$ & $1 \mathrm{~min}$ & $1 \mathrm{~min}$ & $10 \mathrm{~min}$ \\
\cline { 2 - 4 } & \multicolumn{3}{|c}{$40 \mathrm{cycles}$} \\
\hline
\end{tabular}

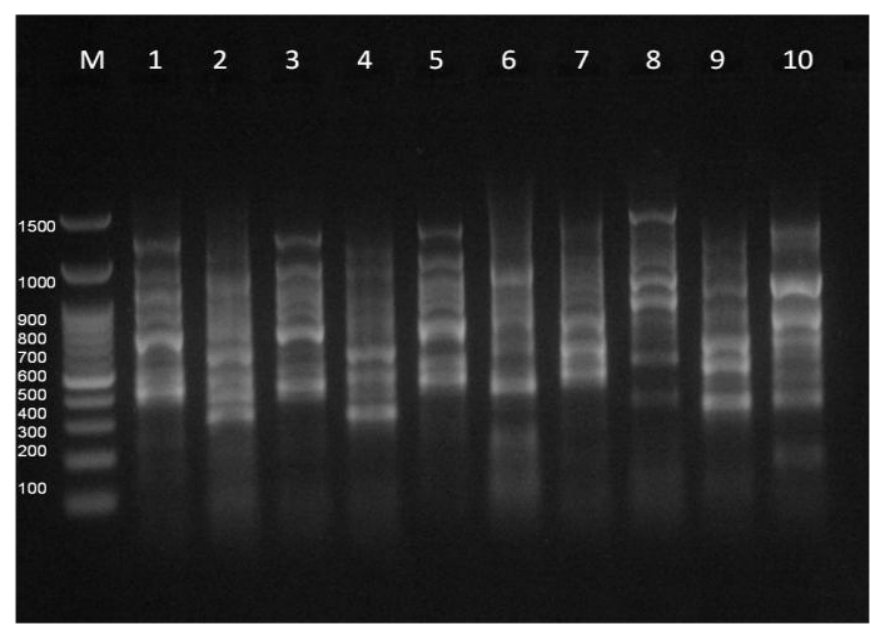

Figure 1:- RAPD PRIMER

5'AGACGGCTCC3'GEL IMAGE

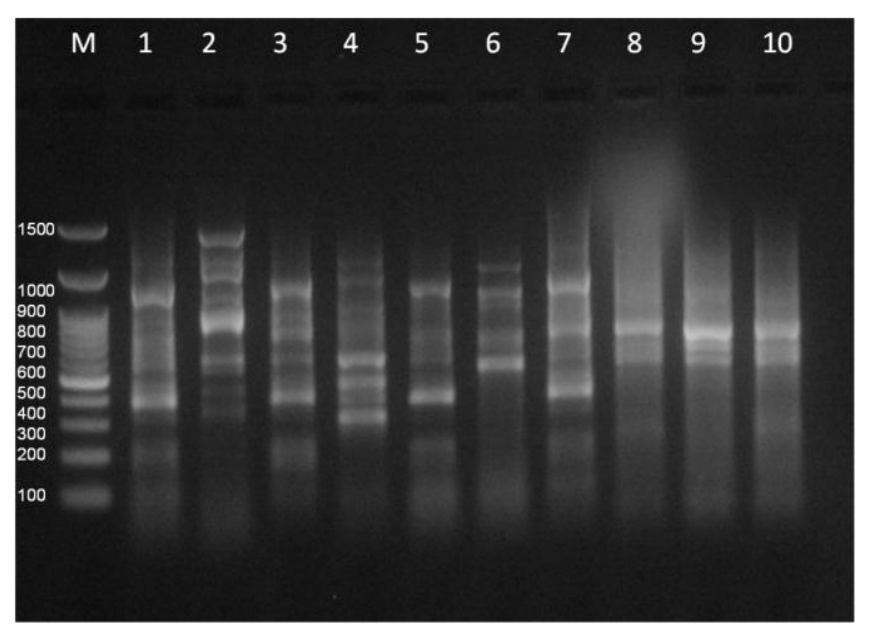

Figure 2:- RAPD PRIMER

5'GAGACCAGAC3' GEL IMAGE 


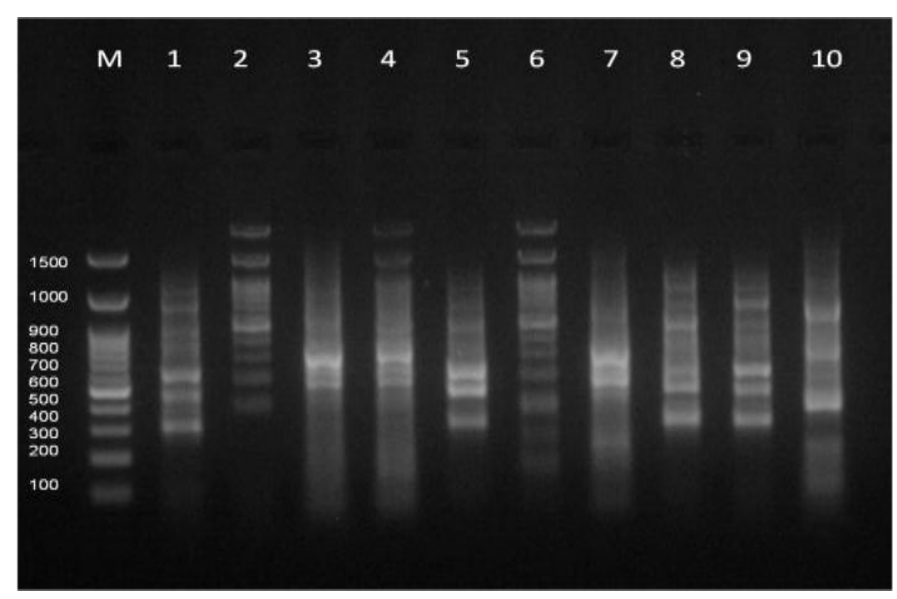

Figure 3:- RAPD PRIMER

5'TTAGCGCCCC 3'GEL IMAGE

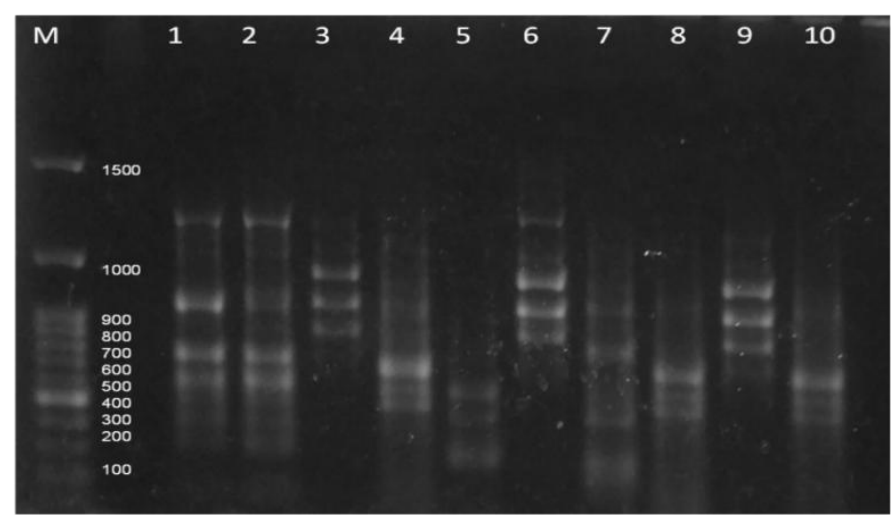

Figure 5:- RAPD PRIMER

5'GTGGGTGCCA3' GEL IMAGE

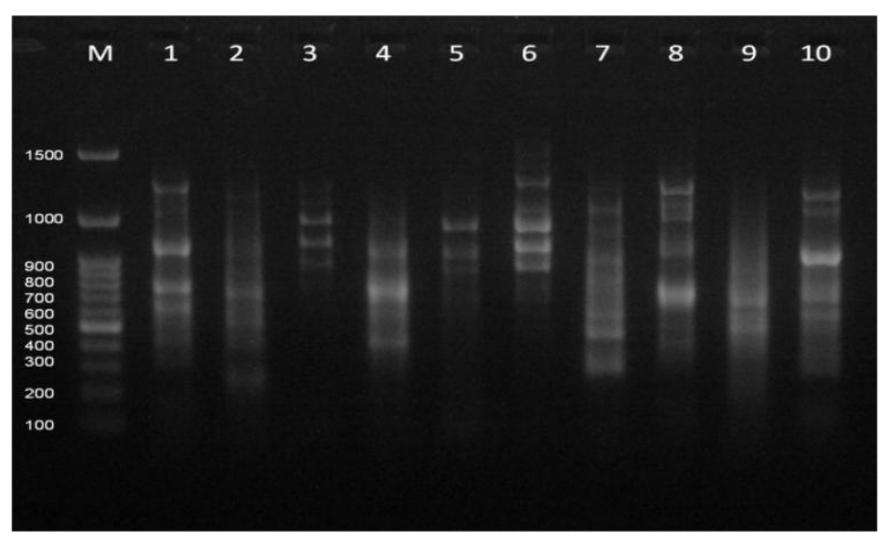

Figure 7:- RAPD PRIMER

5'AGATGGGCAG 3' GEL IMAGE

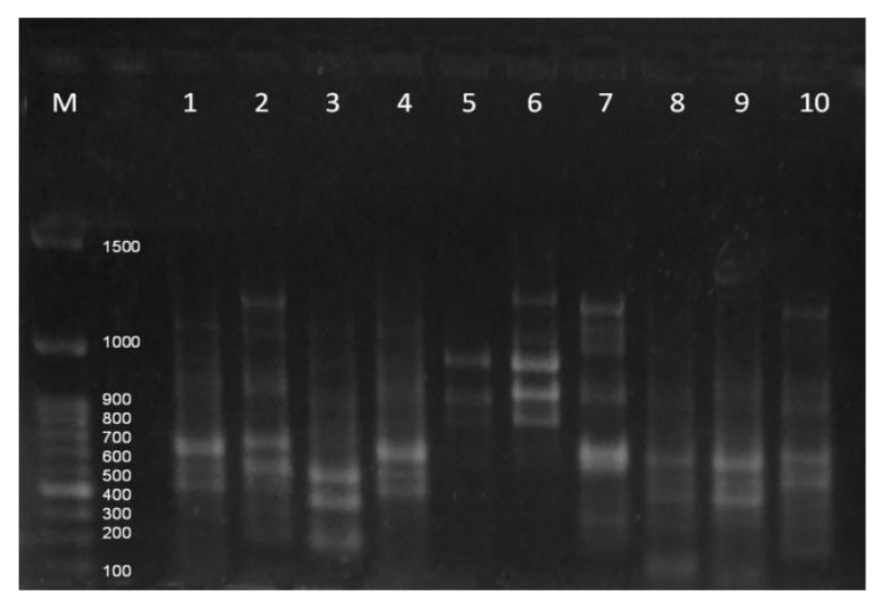

Figure 4:- RAPD PRIMER

5'AGGACTGCTC3' GEL IMAGE

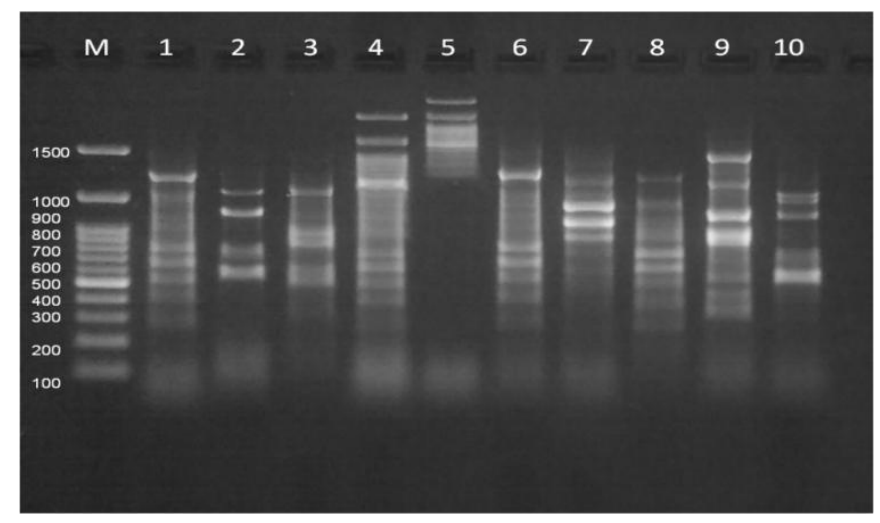

Figure 6:- RAPD PRIMER

5'CTACGCTCAC3' GEL IMAGE

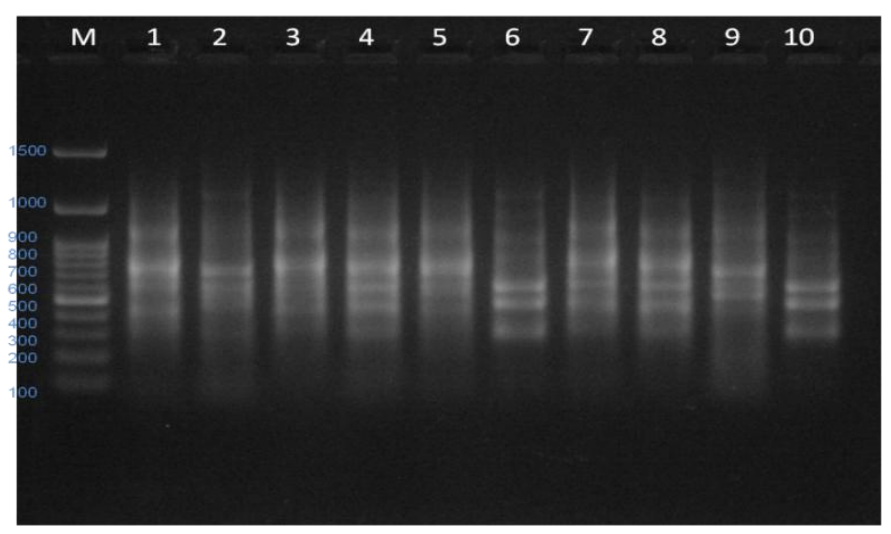

Figure 8:- RAPD PRIMER

5'TGGTCGGGTG3' GEL IMAGE 


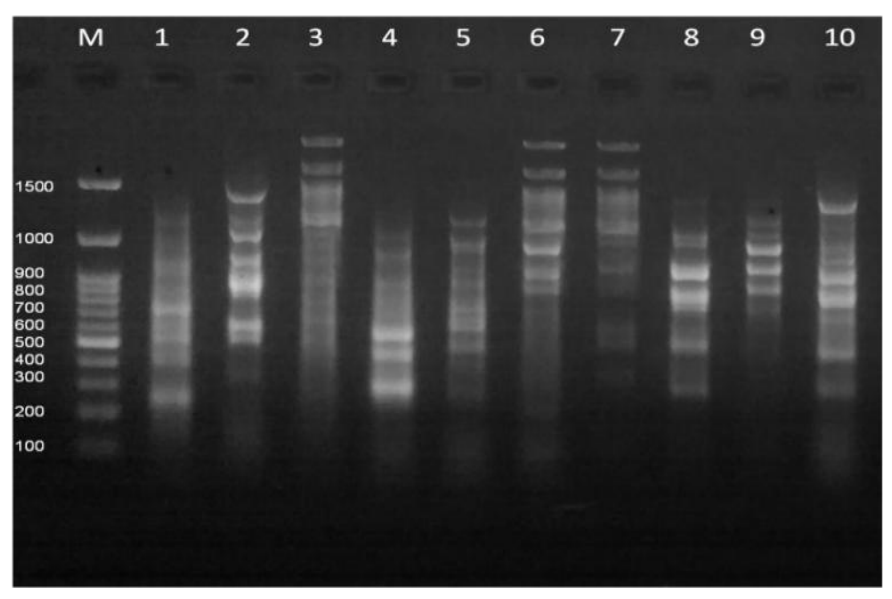

Figure 9:- RAPD PRIMER

5' GGACCCAACC 3' GEL IMAGE

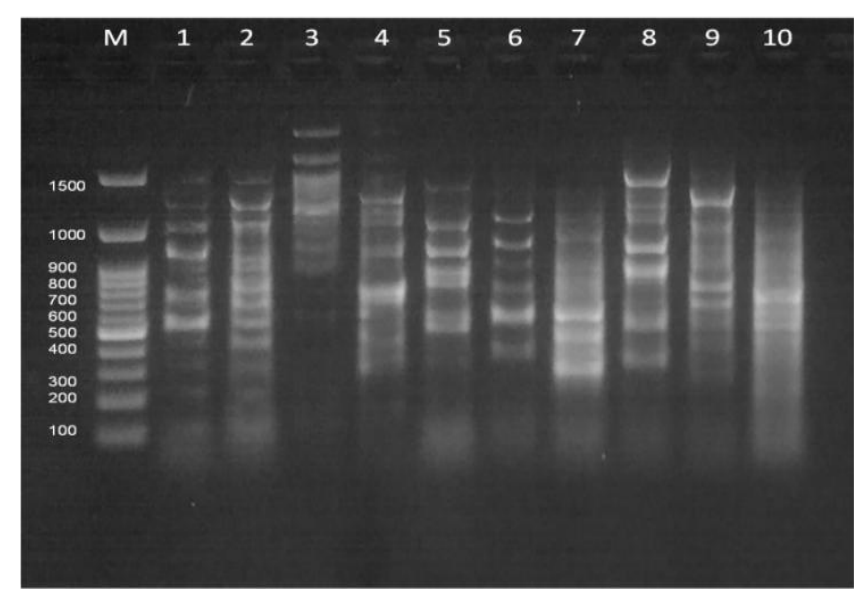

Figure 10:- RAPD PRIMER

5'CAGGCCCTTG3' GEL IMAGE

\section{DENROGRAM (Figure 11)}

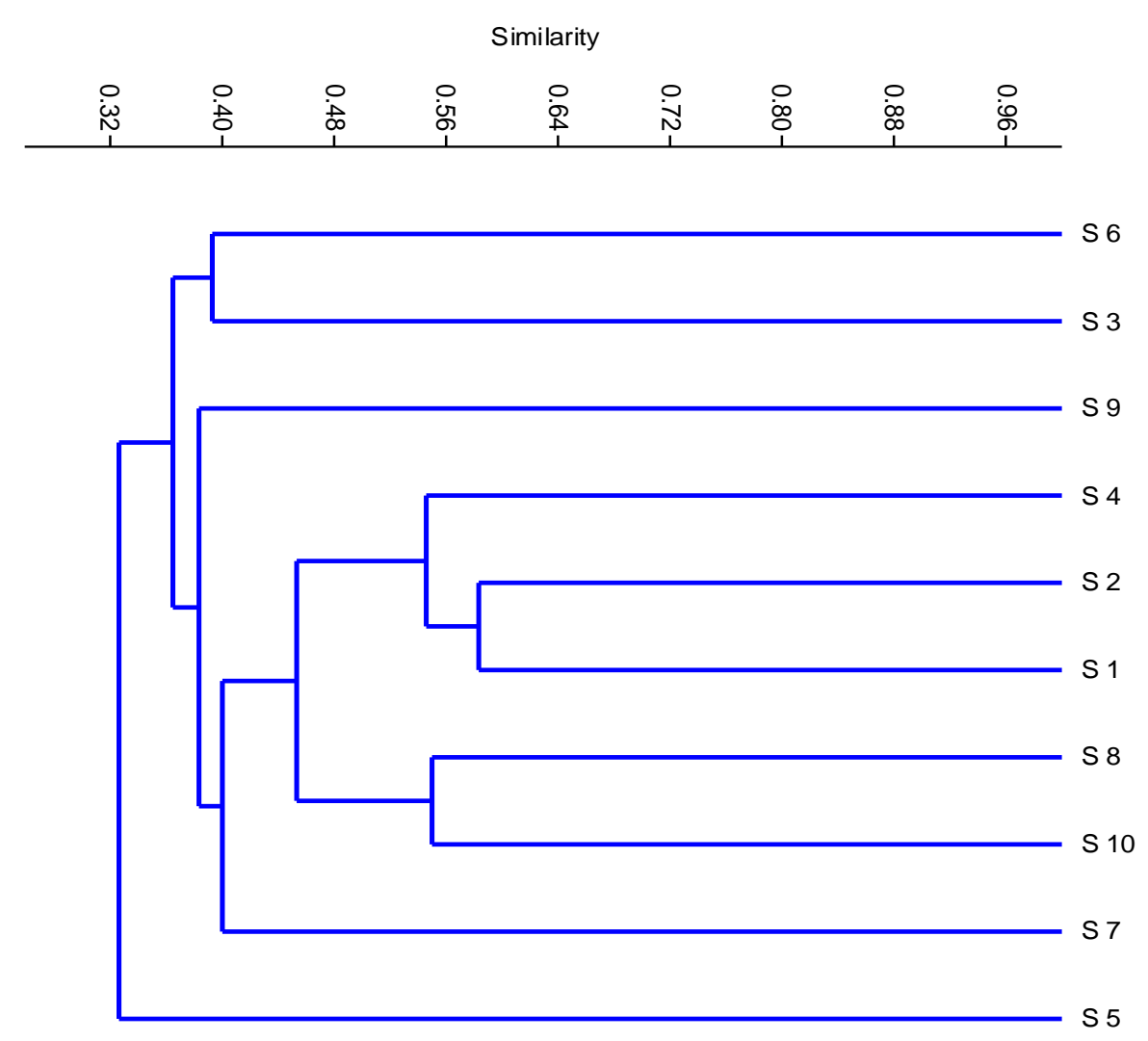


Table.4 DNA extraction - Ratio and yield of 10 genotypes used for RAPD profile

\begin{tabular}{|l|l|c|c|c|}
\hline $\begin{array}{l}\text { Sample } \\
\text { (Genotypes) }\end{array}$ & \multicolumn{1}{|c|}{ Location } & $\begin{array}{c}\text { Ratio } \\
(260 / 280)\end{array}$ & $\begin{array}{c}\text { Ratio } \\
(260 / 230)\end{array}$ & $\begin{array}{c}\text { Yield } \\
(\mu \mathrm{g} / \mathrm{gm})\end{array}$ \\
\hline $\mathbf{1}$ & $\begin{array}{l}\text { Wada, Tal. Vasai } \\
\text { Dist. Palghar, Maharashtra }\end{array}$ & 1.781 & 0.732 & 636 \\
\hline $\mathbf{2}$ & $\begin{array}{l}\text { Wada, Tal. Vasai } \\
\text { Dist. Palghar, Maharashtra }\end{array}$ & 1.818 & 0.699 & 548 \\
\hline $\mathbf{3}$ & $\begin{array}{l}\text { Wada, Tal. Vasai } \\
\text { Dist. Palghar, Maharashtra }\end{array}$ & 1.854 & 0.854 & 561 \\
\hline $\mathbf{4}$ & $\begin{array}{l}\text { Wada, Tal. Vasai } \\
\text { Dist. Palghar, Maharashtra }\end{array}$ & 1.897 & 0.832 & 691 \\
\hline $\mathbf{5}$ & $\begin{array}{l}\text { Wada, Tal. Vasai } \\
\text { Dist. Palghar, Maharashtra }\end{array}$ & 1.732 & 0.751 & 789 \\
\hline $\mathbf{6}$ & $\begin{array}{l}\text { Bhavan's College campus } \\
\text { Andheri (Mumbai) } \\
\text { Maharashtra }\end{array}$ & 1.826 & 0.711 & 610 \\
\hline $\mathbf{7}$ & $\begin{array}{l}\text { Bhavan's College campus } \\
\text { Andheri (Mumbai) } \\
\text { Maharashtra }\end{array}$ & 1.881 & 0.810 & 812 \\
\hline $\mathbf{8}$ & $\begin{array}{l}\text { Bhavan's College campus } \\
\text { Andheri (Mumbai) } \\
\text { Maharashtra }\end{array}$ & 1.719 & 0.891 & 716 \\
\hline $\mathbf{9}$ & $\begin{array}{l}\text { Dahanu } \\
\text { Dist. Palghar, Maharashtra }\end{array}$ & 1.829 & 0.858 & 632 \\
\hline Chennai & 1.845 & 0.692 & 530 \\
\hline
\end{tabular}

Table.5 Similarity matrix computed with Jaccard coefficient

\begin{tabular}{|l|l|l|l|l|l|l|l|l|l|l|}
\hline & S1 & S2 & S3 & S4 & S5 & S6 & S7 & S8 & S9 & S10 \\
\hline S1 & 1 & 0.583 & 0.439 & 0.508 & 0.400 & 0.419 & 0.421 & 0.500 & 0.364 & 0.377 \\
\hline S2 & & 1 & 0.349 & 0.583 & 0.311 & 0.422 & 0.448 & 0.448 & 0.368 & 0.434 \\
\hline S3 & & & 1 & 0.367 & 0.367 & 0.393 & 0.365 & 0.365 & 0.354 & 0.235 \\
\hline S4 & & & & 1 & 0.400 & 0.375 & 0.350 & 0.500 & 0.415 & 0.460 \\
\hline S5 & & & & & 1 & 0.304 & 0.320 & 0.320 & 0.224 & 0.289 \\
\hline S6 & & & & & & 1 & 0.375 & 0.375 & 0.340 & 0.327 \\
\hline S7 & & & & & & & 1 & 0.373 & 0.391 & 0.409 \\
\hline S8 & & & & & & & & 1 & 0.362 & 0.550 \\
\hline S9 & & & & & & & & & 1 & 0.400 \\
\hline S10 & & & & & & & & & & 1 \\
\hline
\end{tabular}

Selection of more geographically diverse genotypes from North and south part of India will help to find out the individual heterozygosity to estimate the best individuals in the population and this data may be correlated with other features of the variety to identify the superior variety. 
In conclusion, Madhuca longifolia commonly called as North Indian mahua or mahua in north and South Indian mahua or illupai is an important non-timber tree which is economically viable but is often neglected due to its common exploitation in production of liquor. Madhuca longifolia is rich in interfering agents such as polyphenols and polysaccharides hence PCR amplification is a difficult task as DNA extracted is of poor quality. The current study focused on generating an RAPD profile using PCR, thus revealing valuable information and forming the basis of a powerful tool for further research. Genetic variation estimated in this report provides the basis for in situ and ex situ conservation programme of genetic resources. Information on the spatial structure of natural populations of Madhuca longifoliathrows insights into the history, isolation, and diversification of its two varieties.

\section{References}

Belaj, A., Satovic, Z., Rallo, L. and Trujillo, I. 2002. "Genetic diversity and relationships in olive (Olea europaea L.)germplasm collections as determined by randomly amplified polymorphic DNA". Theor. Appl. Genet., (online DOI 10.1007/s00122002-0981-6).

AbiyaChelliah, D., A. John De Britto, R.
Mahesh and N. Nirmal Kumar. 2010."'Genetic analysis of VitexnegundoL. using RAPD markers", Biores. Bull., 2: 97-99.

Patil, D.A., Shubhangi Pawar, M.V., Patil. 2004. "Mahua tree and the aborigines of North Maharashtra" Natural Product Radiance, 3(5): 356-358.

Shivashankar, M. 2014. "Random Amplified Polymorphic DNA (RAPD) Markers in Anticancer Drug Plants", Int.J.Curr.Microbiol.App.Sci., $\quad 3(7)$ : 1091-1101.

Rohlf, F.J. 1998. NTSYSpc: Numerical Taxonomy and Multivariate Analysis System. Version 2.02.Exeter Software, Setauket, New York.

Sambrook, Russell. 2000. Molecular Cloning: A Laboratory Manual. 3ed (ed) CSHL Press. 78-85.

Shan, F., Clarke, H.C., Plummer, J.A., Yan, G. and Siddique, K.H.M. 2005. Geographical patterns of the genetic variation in the world collections of wild annual Cicer characterized by amplified fragment length polymorphisms. Theor. Appl. Genet., 110: 381-391.

Singh, P.C., Prasad, D., Singhal, V. and Randhawa, G.J. 2002. Analysis of genetic diversity in Cicer arietinum L. using RAPD markers. J. Plant Biochem. Biotechnol., 11: 109-112.

\section{How to cite this article:}

Rohan Gavankar and Maya Chemburkar. 2016. Genetic Analysis of Madhuca longifolia (J. Koenig ex L.) J.F. Macbr. Using RAPD Markers. Int.J.Curr.Microbiol.App.Sci. 5(8): 608-615. doi: http://dx.doi.org/10.20546/ijcmas.2016.508.068 